'Г.К. Лавренченко, доктор техн. наук; ${ }^{2}$ О.В. Дьяченко, канд. техн. наук 'ООО «Институт низкотемпературных энерготехнологий», а/я 188, г. Одесса, Украина, 65026

${ }^{2} \mathrm{OOO}$ «Криоин Инжиниринг», Таможенная пл., 1А, г. Одесса, Украина, 65026

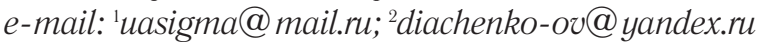

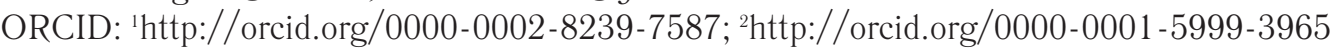

\title{
ОПИСАНИЕ ФАЗОВЫХ РАВНОВЕСИЙ В БИНАРНЫХ СМЕСЯХ — РАБОЧИХ ТЕААХ ХОАОАИАЬНЫХ И КРИОГЕННЫХ СИСТЕМ
}

\begin{abstract}
Бинарные смеси находят применение в качестве рабочих тел в системах холодильной и криогенной техники. Дана общая характеристика основных типов фазовых равновесий в смесях, которые могут использоваться в эффективных холодильных машинах и криогенных установках. Излагается разработанный метод и надёжный алгоритм расчёта фазовых равновесий в бинарных смесях жидкость-пар, жидкость-жидкость и жидкость-жидкость-пар при различных концентрациях, в том числе и соответствующих бинарным гомогенным или гетерогенным азеотропам. Методика не предъявляет никаких специальных требований к виду уравнений состояния. Необходимо только, итобы используемое уравнение состояния было единым, т.е. описывало жидкость и пар и удовлетворяло точностью определения термических и калорических свойств смесей.
\end{abstract}

Ключевые слова: Холодильная машина. Криогенная установка. Бинарная смесь. Фазовое равновесие. Фугитивность. Растворимость. Единое уравнение состояния.

\section{BBEAEHИE}

На эффективности действительных циклов холодильных и криогенных систем заметно сказываются свойства используемых в них хладо- или криоагентов. Известно, что только характеристики цикла Карно не зависят от рода рабочего тела. Что же касается циклов, реализуемых с внутренней и внешней необратимостью, то на их показатели существенно влияют термодинамические и другие свойства применяемых рабочих тел.

Ввиду этого создатели низкотемпературных рефрижераторных систем пытаются выбирать наилучшее рабочее тело. На заключительном этапе, чтобы окончательно определиться с ним, принимают во внимание также и эксплуатационные (токсичность, пожароопасность, растворимость в компрессорном масле), и экологические характеристики (исключение влияния на озоновый слой атмосферы, минимизация вклада в парниковый эффект).

Часто рабочее тело с приемлемыми характеристиками выбрать среди чистых веществ не удается. Поэтому прибегают к формированию более эффективных бинарных рабочих тел.

Применение смесей в качестве рабочих тел в низкотемпературных компрессорных системах имеет длительную историю. Известны многочисленные исследования в этой области, которые по разным причинам получили незначительное практическое развитие. Несмотря на это, смеси веществ, в том числе и бинарные, продолжают интересовать как разработчи- ков систем холодильной и криогенной техники, так и тех, кто занимается исследованиями их термодинамических свойств.

Рассмотрим примеры эффективного применения смесей веществ в холодильных компрессорных машинах.

Отметим, что в качестве рабочих тел предлагались гомогенные двухкомпонентные смеси. На рис. 1 приведён вид фазовых равновесий в неазеотропных и азеотропных растворах в $T, y, x$-координатах. Там же показано изменение параметров смесей в $y, x$-диаграмме [1].

Из указанных растворов чаще всего используются азеотропные бинарные рабочие тела. Свойства наиболее известных из них указаны в [2].

Для замены озоноразрушающих веществ на альтернативные хладагенты нами были разработаны и исследованы бинарные азеотропы, имеющие нулевой потенциал разрушения озонового слоя. Сравнительные исследования этих хладагентов на стенде с калориметром показали более высокую эффективность по сравнению с R134а [3].

Эффективность бинарных неазеотронов не так очевидна. Однако при оптимизации их составов можно достигать достаточно высоких термодинамических характеристик. Объясняется это тем, что потери в циклах холодильных машин, обусловленные неизотермичностью процессов кипения и конденсации неазеотропных смесей, удаётся компенсировать развитой эффективной регенерацией тепла [4].

Относительно новым можно признать применение в циклах малых холодильных машин смесей с ограни- 